\title{
The New Arab Cold War: rediscovering the Arab dimension of Middle East regional politics
}

\author{
MORTEN VALBJØRN AND ANDRÉ BANK*
}

\begin{abstract}
This article provides a conceptual lens for and a thick interpretation of the emergent regional constellation in the Middle East in the first decade of the 21st century. It starts out by challenging two prevalent claims about regional politics in the context of the 2006 Lebanon and 2008-09 Gaza Wars: Firstly, that regional politics is marked by a fundamental break from the 'old Middle East' and secondly, that it has become 'post-Arab' in the sense that Arab politics has ceased being distinctly Arab. Against this background, the article develops the understanding of a New Arab Cold War which accentuates the still important, but widely neglected Arab dimension in regional politics. By rediscovering the Arab Cold War of the 1950-60s and by drawing attention to the transformation of Arab nationalism and the importance of new trans-Arab media, the New Arab Cold War perspective aims at supplementing rather that supplanting the prominent moderate-radical, sectarian and Realist-Westphalian narratives. By highlighting dimensions of both continuity and change it does moreover provide some critical nuances to the frequent claims about the 'newness' of the 'New Middle East'. In addition to this more Middle East-specific contribution, the article carries lessons for a number of more general debates in International Relations theory concerning the importance of (Arab-Islamist) non-state actors and competing identities in regional politics as well as the interplay between different forms of sovereignty.
\end{abstract}

Morten Valbjørn is Assistant Professor at the Department of Political Science, Aarhus University, Denmark. He can be contacted at: \{mortenv@ps.au.dk\}.

André Bank is a Research Fellow at the German Institute of Global and Area Studies, Institute of Middle East Studies, Hamburg, Germany. He can be contacted at: \{bank@gigahamburg.de\}.

\section{Introduction}

If two of the major US objectives of toppling Saddam Hussein's regime in 2003 were to change the overall dynamics in the Middle East and to reconstruct a new

\footnotetext{
* Earlier versions of this article were presented at the Annual Conference of the International Studies Association in New York in 2009, at the International Relations section of the Department of Political Science at Aarhus University as well as the Institute for Peace Research and Security Policy in Hamburg, both in 2010. The authors would like to thank Thomas Richter, Seth Rogoff, Avraham Sela as well as three anonymous reviewers for insightful comments and productive criticism.
} 
Pax Americana, as argued by proponents of the Bush doctrine, ${ }^{1}$ then the US invasion of Iraq seems to have accomplished at least the former. Most observers agree that today's Middle East is fundamentally different from regional politics in the pre-2003 period. There is no general consensus, however, about the broader question concerning the nature of the emerging regional constellation. Against this background and in the context of the growing attention in the general International Relations debate on the need to pay more attention to distinct dynamics at the regional level, ${ }^{2}$ it is thus hardly surprising that one of the current main debates on the region centres on the nature of this 'New Middle East'. ${ }^{3}$ While conclusions differ, many analysts concur on at least two points. First, their point of departure is a distinction between an old and a new Middle East, in which the latter is characterised by distinctly new regional dynamics qualitatively different from earlier days. This is reflected in the absence of one of the most prominent themes in twentieth century discussions about Middle East politics: the impact of Arab nationalism on regional politics. This issue is presented as a thing of the past or simply ignored. Instead regional politics in the 'New Middle East' is assumed to be driven either by 'normal' Westphalian raison d'état logics or by new region-specific dynamics reflecting cleavages within Islam or between so-called moderates and radicals. Thus, a second striking consistency in the overall debate is a consensus on how Arab politics has ceased to be distinctly Arab. Even the very existence of an Arab World has been put into question by observers writing it off as nothing but a mirage in the Middle Eastern desert. ${ }^{4}$ Hence, in all of these various post-Arab 'New Middle Easts' an analytical distinction between a larger Middle East and the Arab world appears to have lost any relevance to our understanding of regional politics.

In this debate on the nature of the allegedly very New Middle East after the Iraq War 2003 it is useful to recall the late Fred Halliday's remark about how 'there are two predictable and nearly always mistaken responses to any great international upheaval: one is to say that everything has changed; the other is to say that nothing has changed. ${ }^{5}$ Following this warning, our overall aim is to challenge and to provide some nuances to these two claims about the 'newness' and 'post-Arab' nature of a 'New Middle East'. Thus, we are suggesting first that the notion about an Arab world is less obsolete than commonly held; a transformed

${ }^{1}$ Raymond Hinnebusch, 'Hegemonic Stability Theory Reconsidered: Implications of the Iraq War', in Rick Fawn and Raymond Hinnebusch (eds), The Iraq War: Causes and Consequences (Boulder: Lynne Rienner, 2006), pp. 297-8.

2 Cf. Rick Fawn, 'Regions and their study: wherefrom, what for and whereto?', Review of International Studies, 35 (2009), pp. 5-34; Andrew Hurrell, 'One world? Many worlds? The place of regions in the study of international society', International Affairs, 83 (2007), pp. 127-46; Barry Buzan and Ole Wæver, Regions and Powers - The Structure of International Security (Cambridge: Cambridge University Press, 2003).

${ }^{3}$ Cf. Richard N. Haass, 'The New Middle East', Foreign Affairs, 85 (2006), pp. 2-12; Alexander T. J. Lennon (ed.), The Epicenter of Crisis. The New Middle East (Cambridge: MIT Press, 2008); Robert Malley and Peter Harling, 'Beyond Moderates and Militants', Foreign Affairs, 89 (2010), pp. 18-29; Vali Nasr, The Shia Revival: How Conflicts Within Islam Will Shape the Future (New York: Norton, 2007); Marina Ottaway et al., The New Middle East (Washington DC: Carnegie Endowment for International Peace, 2008); Nicolas Pelham, A New Muslim Order: The Shia and the Middle East Sectarian Crisis (London: I. B. Tauris, 2008); Philip Seib, New Media and the New Middle East (New York: Palgrave, 2009).

${ }^{4}$ Eyal Zisser, 'Trends in Middle East Politics and their Implications for Israel', Israel Affairs, 12 (2006), p. 688.

5 Fred Halliday, 'A New Global Configuration', in Ken Booth and Timothy Dunne (eds), Worlds in Collision - Terror and the Future of Global Order (New York: Palgrave, 2002), p. 235. 
form of Arab nationalism, we assert, still influences the nature of regional politics today. Secondly, we suggest that the 'Old Middle East' - not of the 1990s but of the 1950-60s - provides a useful analytical lens for grasping some of the present dynamics. Our key argument is that what we call a New Arab Cold War refers to a very relevant but widely neglected $A r a b$ dimension of contemporary regional politics in the Middle East. By using the term New Arab Cold War we deliberately paraphrase Malcolm Kerr's seminal study of ideological rivalry in Middle East politics during the $1950-60 \mathrm{~s}^{6}$ Thus, we argue that it is possible to identify a number of structural similarities between some of today's regional dynamics and the Old Arab Cold War, including a distinct overarching Arab framework of regional rivalry revolving around the Palestine question.

By this we point at dimensions of continuity disregarded in much of the current debate on the profound newness of the 'New Middle East'. Recalling the second part of Halliday's warning, this does however not imply that we are suggesting that nothing has changed. By referring to a New Arab Cold War we do at the same time indicate how the current rivalry displays important differences from the old: though having a distinct Arab dimension, it takes place within the framework of a new kind of Arab nationalism which is related to the emergence of new trans-Arab media. Contrary to the Old Arab Cold War, which was to a large extent waged between Arab states on the regional and domestic levels, today's variant contains a stronger regime/society dimension, where the 'radical' block is dominated by societal actors advocating an Arab-Islamic order with a considerable resonance within the Arab public. The nature and impact of this 'radical' challenge also differs from the 1950-60s, which was associated with coup d'états and grand pan-Arab unity schemes implying the dissolution of the existing Arab state system. Today it is rather reflected in a growing delink between states and societies as well as the emergence of a parallel non-statist Arab order existing side by side and being in tense relationship with the official Arab state system.

This argument for a qualified return to the Arab Cold War conception is advanced in four steps and takes its point of departure in the first major regional conflict in the 'new' post-Iraq War Middle East: the 2006 Lebanon War. Despite all the controversies relating to Condoleezza Rice's remark on how the 2006 Lebanon War constituted the 'birth pangs of a new Middle East', ${ }^{7}$ she was far from alone in perceiving the violent conflict between Israel and Hizballah as well as the diverse and intensive reactions to it as a prism through which the nature of the emerging regional constellation could be grasped. Our first step, therefore, is to evaluate the central claims about what the 2006 Lebanon War tells us about the 'new Middle East' (section 2). Based on a critique of these narratives, mainly on the grounds that they ignore the Arab dimension in the regional reactions, the second step brings us back to the Arab Cold War in the 'Old Middle East' (section 3). Following an outline of the distinct features of Arab politics in that era, we

${ }^{6}$ Malcolm Kerr, The Arab Cold War, 1958-1964. A Study of Ideology in Politics (London: Oxford University Press, 1965). It is important to stress that our intention is not to draw parallels to the rivalry between the superpowers during the global 'Cold War' as the case has been with some of the recent calls to contain and deter Iran in a manner similar to the USSR. Besides the 'cold' dimension, that is, the ideological nature of the rivalry carried on by methods short of sustained overt military action, the reason for employing the notion about an 'Arab Cold War' is instead to bring attention to similarities with distinct features of Arab politics during the 1950-60s, the era examined by Kerr.

${ }^{7}$ Condoleeza Rice, Special Briefing on Travel to the Middle East and Europe (21 July 2006). 
address the question of whether - to paraphrase Jerrold Green ${ }^{8}$ - 'Arab politics is still Arab' and conclude that Arab nationalism has been transformed rather than terminated. In the third step, the implications of the 2006 Lebanon War for regional order are re-evaluated and our understanding of a New Arab Cold War is outlined in detail (section 4). In order to examine whether the dynamics of this New Arab Cold War constitute a more general pattern, as the fourth step, we compare continuities and changes in the regional reactions between the Lebanon War 2006 and the Gaza War 2008-09 (section 5).

Against this background we conclude that the conception of a 'New Arab Cold War' allows us to grasp an important dimension of regional politics neglected in much of the contemporary debate on the New Middle East. Thus, we do not claim that Arab nationalism is all there is or that all regional dynamics should be reduced to a New Arab Cold War. Agreeing with another advice from Halliday about the need of a diversity of analytical foci and of the importance of avoiding the reduction of the Middle East to one particular conflict, ${ }^{9}$ our aim is thus to supplement rather than supplant the existing perspectives on the nature of contemporary regional dynamics. As will be further outlined in the conclusion, the article does in addition to this more Middle East specific contribution carry important lessons for a number of more general debates in International Relations (IR) theory. In this way, the article also points at some of the merits of bringing regional specialists and IR generalists into a closer dialogue.

\section{Contending visions of a 'New Middle East': the 2006 Lebanon War}

Besides the very violent conflict with Israel, Hizballah was during the summer 2006 also engaged in a bloodless collision with Egypt, Saudi Arabia and Jordan. Then-Egyptian president Husni Mubarak and Jordanian King Abdallah II accused Hizballah of 'dragging the region in adventures' and Saudi officials spoke of Hizballah's 'irresponsible adventurism'. ${ }^{10}$ This position was supported by regimeinfluenced media outlets such as the newspaper al-Sharq al-Awsat and the satellite channel al-Arabiya.

During and after the 34 days of 'hot' clashes between Israeli forces and Hizballah, various analysts used this 'cold' regional conflict to advance a variety of claims about the nature of the 'New Middle East'. The aforementioned 'birth pangs'-remark by Rice relates to what may be labelled the moderate-radical narrative about how Lebanon 2006 is closely related to a regional transformation. During the (in)famous press conference, the US secretary of state also explained how the region was now divided between 'violent radicals' and 'moderate reformists'. The former were represented by the Lebanese Hizballah and the Palestinian Hamas which were charged with strangling the new democratic governments in the region. The 'moderates' were led by Egypt, Saudi Arabia and Jordan and represented, according to Rice, a consensus of the leading regional

\footnotetext{
8 Jerrold Green, 'Are Arab Politics Still Arab?', World Politics, 38 (1986), pp. 611-25.

${ }^{9}$ Fred Halliday, The Middle East in International Relations - Power, Politics and Ideology (Cambridge: Cambridge University Press, 2005), p. 321.

10 Amr Hamzawy, 'Adventurism versus submission', Al-Ahram Weekly Online, 805 (2006).
} 
powers that Islamist extremism constituted the key source of the Middle East's problems. During the 2006 Lebanon War, these moderates had for this reason joined the US and Israel in an effort to push forward to a truly New Middle East, which besides having lasting peace and stability would be characterised by pro-Western democratic regimes, as exemplified then by the Siniora government in Lebanon.

While this moderate-radical distinction gained considerable prominence during the conflict, an even more popular way of framing the regional dimensions of the 2006 Lebanon War can be described as the sectarian narrative. Here, regional reactions pointed to an emerging Sunni-Shi'i divide in an increasingly post-Arab Middle East. According to Asser Susser, the regional reactions to the Lebanon War illustrated that the very notion of an Arab world had lost any relevance for understanding politics in this part of the globe. Accordingly, the 2006 War should not be perceived as yet another Arab-Israeli war. Instead, it was the first encounter between Israel and Iran, who as 'the expansionist aspiring hegemon at the heart of the Shiite Crescent' also constituted the new major threat to the 'moderate' post-Arab Shi'i states. ${ }^{11}$ In a similar vein, Vali Nasr suggested that the 2006 Lebanon War marked a spill-over of sectarian tensions manifest in post-Saddam Iraq. In his view, this confirmed his prophesy that whereas the dominant political value of the 'Old Middle East' had been Arab nationalism, the 'New Middle East' would be defined by sectarian cleavages within Islam. ${ }^{12}$

At first sight, this sectarian narrative appears more convincing than the moderate-radical reading, which to some extent turns the world upside-down: some of the 'moderate reformists' are to a large extent status quo-oriented Arab autocrats with limited popular legitimacy. ${ }^{13}$ In turn, some of the reformers and democratically inclined actors in the region can in fact be found in the so-called 'radical' camp. ${ }^{14}$ As for the sectarian reading of the Lebanon War, Egypt, Jordan and Saudi Arabia's decisions to publicly criticise an Arab movement's decision to confront Israel, thus breaking one of the classic taboos in the 'Arab game of politics', is not only presented as proof of how Arab politics has ceased to be distinctly Arab. It is also interpreted as a sign of how the new game is based on sectarian rules. Thus, during the conflict, Egypt, Jordan and Saudi Arabia were consistently labelled as the 'moderate Sunni Arab' countries in both pro-regime and Western media. In turn, Hizballah was described as a Shi'i movement, which, moreover, was presented as nothing but a pawn of a Shi'i-Persian Iran and its 'quasi-Shi'i' Syrian ally.

Upon closer inspection, this picture of a post-Arab Middle East order based on sectarian rifts within Islam begins to blur in a number of ways. What may appear as a Shi'i vs. Sunni alignment based on sectarian concerns could - according to what may be labelled a Westphalian narrative - be read as nothing but an expectable reaction from regional states trying to balance a rising regional power,

${ }^{11}$ Asher Susser, 'Iraq, Lebanon and Gaza: Middle Eastern Trends'. Tel Aviv Notes (23 July 2007).

12 Nasr, Shia Revival. Cf. also Pelham, New Muslim Order.

${ }^{13}$ Cf. Mark Sedgwick, 'Measuring Egyptian Regime Legitimacy', Middle East Critique, 19 (2010), pp. 251-67. Egyptian president Mubarak, one of the quintessential 'moderate reformists', was also among the first to fall in the 'Arab Spring' of 2011.

14 Daniel Levy, 'Picking up the Peace', Prospect for Peace Blog (21 January 2009). Cf. also Malley/Harling, 'Beyond Moderates'. 
that is, Iran, Shi'i or not. Following this logic, which draws on insights from Realist IR theory, the alignment of Sunni states during the 2006 Lebanon War has less to do with an emerging Shi'i-Sunni conflict than with a classic raison d'état logic of states working in an anarchic state system. ${ }^{15}$ The official anti-Shi'i rhetoric was thus primarily for the 'moderate' states' internal consumption as large parts of their population saw Israel, together with the US, as far greater threats to regional security than Iran (see also below).

If the spectre of a 'Shi'i Crescent' is explained as an attempt at selling at home an unpopular foreign policy based on non-sectarian motives, this not only draws attention to yet another reason why the sectarian narrative appears unconvincing. It does also indicate why it is useful to broaden the focus from the narrow interstate level of the Realist-inspired Westphalian narrative. By including the substate level and societal actors it thus becomes very difficult to recognise a distinct Sunni-Shi'i divide at all. Here, a different cleavage is revealed. During the 2006 Lebanon War intersectarian sympathies were not limited to the Shi'i Hizballah and the Sunni Hamas, both directly involved in the conflict. Popular expressions of sympathy and support for Hizballah resounded throughout the predominantly Sunni Arab world: trans-Arab media such as the satellite channel al-Jazeera, usually charged with being Sunni-biased, took a pro-Hizballah stance; prominent Sunni Islamist intellectuals as Shaykh Yusuf al-Qaradawi ${ }^{16}$ called for Sunni-Shi'i cooperation, castigating the Saudi critique of Hizballah; Sunni Islamist movements such as the Muslim Brotherhood wings in, for example, Egypt and Jordan, lent their full support to Hizballah and organised demonstrations also joined by non-Islamist opposition groups such as the Egyptian Kifaya movement. ${ }^{17}$ In regional opinion polls made during and after the conflict, the head of Hizballah, Sayyid Hassan Nasrallah ranked as the most admired Arab leader. When asked to identify the biggest external threats to their security almost 80 per cent of respondents in Egypt, Jordan and Saudi Arabia referred to Israel and the US, while only 11 per cent cited Iran. ${ }^{18}$ Against this background, the regional split exposed by the Lebanon War appears less of a Shi'i-Sunni rift than what Marc Lynch has described as a 'regimes-peoples divide' within the so-called 'moderate' Arab states. ${ }^{19}$

Another striking feature at the societal level was the prevalent popular framing of the conflict as it took place within an Arab nationalist narrative. Despite the prevalent claims about the 'post-Arab' nature of today's regional politics, the popular debate was full of well-known Arab nationalist slogans about Arab

${ }^{15}$ F. Gregory Gause, 'Saudi Arabia: Iraq, Iran, the Regional Power Balance, and the Sectarian Question', Strategic Insights, 6 (2007).

16 Being an outstanding legal scholar, a major Islamist ideologist and the famous host of al-Jazeera's most popular religious programme, 'Islamic Law and Life', Yusuf al-Qaradawi is arguably the best-known Sunni religious figure in the Arab world today. Cf. Bettina Graf and Jakob Skovgaard-Petersen (eds), The Global Mufti: The Phenomenon of Yusuf Al-Qaradawi (London: Hurst, 2009).

${ }^{17}$ Kifaya- Arabic for 'enough' - is the popular term for the 'Egyptian Movement for Change'. Cf. Rabab El-Mahdi, 'Enough!: Egypt's Quest for Democracy', Comparative Political Studies, 42 (2009), pp. 1011-39.

18 Shibley Telhami, Anwar Sadat Chair for Peace and Development University of MarylandlZogby International 2006 Annual Arab Public Opinion Survey (8 February 2007).

${ }^{19}$ Marc Lynch, 'Power Ploy - Why three Arab regimes are publicly aligning themselves against Hezbollah and Iran', American Prospect (20 July 2006). 
solidarity, resistance to occupation, and the liberation of Palestine. Moreover, Hizballah not only portrayed itself, but was also popularly perceived as more of an Arab than a Shi'i political movement. Thus, Nasrallah, was praised as 'the only true Arab leader today' and as the 'new Arab Lion'. In Egypt, the opposition played on the coincidence between the Lebanon War and the fiftieth anniversary of Gamal Abdel Nasser's nationalisation of the Suez Canal. In the opposition press comparisons were made between 'Nasrallah 2006' with 'Nasser 1956' and at demonstrations in Cairo, posters depicted the head of Shi'i Arab movement next to the legendary Arab nationalist leader. ${ }^{20}$

Against this background of what the Palestinian-Jordanian columnist Rami Khouri at the time described as a 'revival of a sense of Arab Nationalism', ${ }^{21}$ it is natural to ponder whether the 2006 Lebanon War constitutes less of a push forward to a distinctly new moderate-radical, sectarian or Westphalian post-Arab Middle East than of a return to regional dynamics carrying similarities to those during the heyday of Arab nationalism.

\section{Bringing Arab nationalism back in, carefully}

Before we turn to Arab politics of the 1950-60s and the discussion of whether Arab politics is still Arab, a short conceptual clarification is necessary. Thus, part of the controversy on whether Arab nationalism should be considered obsolete or obstinate can be attributed to different author's use of the same terms for different phenomena. We consider Arab nationalism to be the general idea about the existence of special bonds between Arabic-speaking people, who are assumed to be part of a single Arab nation constituted by common language, history, culture and tradition. ${ }^{22}$ When it comes to the political implications of this view we distinguish between three variants of Arab nationalism: Pan-Arabism, Political Arabism and Cultural Arabism (see also Figure 1). ${ }^{23}$ According to Pan-Arabists, the Arab world constitutes a 'pan-system'. The ultimate goal is territorial unity in terms of a merger of what is considered as artificial Arab territorial states into a 'true' Arab nation-state. Until then the 'raison de la nation Arabe', that is, common Arab interests and security concerns, should always take precedence over a narrow raison d'état. Political Arabists perceive the Arab world as an anarchical international society, where Arabs living in different states are linked by special bonds. Arab politics should reflect this reality and accordingly be informed not

${ }^{20}$ For a further discussion of how Hizballah framed itself and how the movement was popularly portrayed during the Lebanon War $2006 \mathrm{cf}$. Graham Fuller, 'The Hizballah-Iran Connection: Model for Sunni Resistance', The Washington Quarterly, 30 (2006), pp. 139-50; Morten Valbjørn and André Bank, 'Signs of a New Arab Cold War: The 2006 Lebanon War and the Sunni-Shi'i Divide', Middle East Report, 242 (2007), pp. 6-11.

${ }^{21}$ Rami Khouri, 'Heed the Changes in Arab Public Opinion', Agence Global (28 July 2006).

22 On this terminological distinction and the general debate on 'who are the Arabs' cf. Morten Valbjørn, 'Arab Nationalism(s) in Transformation: From Arab Interstate Societies to an ArabIslamic World Society', in Barry Buzan and Ana Gonzalez-Pelaez (eds), International Society and the Middle East - English School Theory at the Regional Level (New York: Palgrave, 2009), pp. 142-4.

23 These three variants of Arab nationalism constitute an analytical distinction, which does not directly correspond with the classical Arabic dichotomy of 'qawmiya' (trans-state Arab nationalism) vs. 'wataniya' (nation-state nationalism). 


\begin{tabular}{|c|c|c|}
\hline \multicolumn{3}{|c|}{$\begin{array}{l}\text { Arab nationalism } \\
\text { Idea that special bonds exist between people speaking Arabic as they belong to the same distinct Arab } \\
\text { nation constituted by common language, history, culture and tradition }\end{array}$} \\
\hline Cultural Arabism & Political Arabism & Pan-Arabism \\
\hline $\begin{array}{c}\text { The Arab World as a } \\
\text { cultural space }\end{array}$ & $\begin{array}{c}\text { The Arab World as an anarchical } \\
\text { international society }\end{array}$ & $\begin{array}{l}\text { The Arab World as a } \\
\text { Pan-system }\end{array}$ \\
\hline
\end{tabular}

Figure 1. Arab nationalism and the various Arabisms.

only by a narrow self-interest but also comply with a number of distinct Arab norms, rules and values including certain obligations and a commitment to solidarity among Arabs. To Cultural Arabists, the Arab world is primarily a cultural space in the sense that Arabs feel a degree of cultural proximity and share common habits and customs, but without implying any substantial political commitments or obligations.

\subsection{Lessons from the past: the Old Arab Cold War}

By turning our attention to the 1950-60s, it becomes clear why it is useful to differentiate between these three forms of Arab nationalism. This era is usually presented as the heyday of Arab nationalism. However, this implied neither much inter-Arab harmony nor consensus among Arabs when it came to the implications of belonging to the same Arab nation. On the contrary, this issue constituted one of the key points of dispute in what Kerr called the 'Arab Cold War' ${ }^{24}$

Though linked to the global Cold War, this regional Cold War was not a mere reflection of the superpower rivalry, as it held a distinct Arab dimension. ${ }^{25}$ This made inter-Arab relations different in kind and not only in degree from other parts of the post-colonial world and at odds with some of the prevalent Westphalian assumptions within the major strands of IR theory. ${ }^{26}$ The regional context was anarchic in terms of a lack of a centralised authority. At the same time, it was marked by a particularly strong sense of supra-state community. This emerged from a widely held Arab nationalist notion about special bonds between Arabspeaking peoples, who were believed to share common 'Arab interests'. Combined with a high level of interconnectedness at the state and societal levels, this made the Arab world into what Paul Noble has famously depicted as a 'vast sound chamber in which information, ideas, and opinions have resonated with little regard for state frontiers'. ${ }^{27}$ Contrary to 'proper nation-states', the Arab states

${ }^{24}$ Kerr, Arab Cold War.

${ }^{25}$ While Kerr also addresses the effects of the international structure of bipolarity on the Middle East, his focus and main contribution is on the 'relative autonomy' of intra-regional dynamics within an Arab framework. On the complex implications of the global Cold War for Middle Eastern regional politics until the early 1990s cf. Raymond Hinnebusch, The International Politics of the Middle East (Manchester: Manchester University Press, 2003), pp. 14ff; Yezid Sayigh and Avi Shlaim (eds), The Cold War and the Middle East (Oxford: Clarendon Press, 1997).

${ }^{26}$ Paul Noble, 'The Arab System: Pressures, Constraints, and Opportunities', in Bahgat Korany and Ali E. Hillal Dessouki (eds), The Foreign Policies of Arab States (Boulder: Westview, 1991), p. 55.

27 Noble, 'Arab System', p. 56. 
were only to be considered as 'territorial states', reflected in the numerous state constitutions declaring that the Arab-speaking people of a given country form a part of the 'Arab nation'. ${ }^{28}$ Due to this state-nation misfit, the classic notion of 'the national interest' became an ambiguous behavioural guide as schisms occurred between a narrow raison d'état and a need to be popularly perceived as being in line with the 'raison de la nation Arabe'. Thus, it was generally agreed that membership in the Arab nation involved solidarity among Arabs and a commitment to Arab 'core issues' with the defence of Palestine as the most prominent. ${ }^{29}$ Apart from such vague notions, it was however highly contested what further implications the idea about special bonds between Arabs had. As a consequence, the nature of rivalry in the Arab Cold War largely arose from the question about the political implications of belonging to the same Arab nation. It was concerned with the ability to monopolise the specific meaning of the 'Arab interest' and to define the associated norms for 'proper' Arab behaviour. ${ }^{30}$ Hence, the basic cleavage in the Arab Cold War was less about whether regional politics should hold a distinct Arab dimension as such than about whether a 'raison de la nation Arabe' should always take precedence in situations in which a commitment to 'common Arab interests' was at odds with the narrow self-interest of a particular Arab territorial state. Put differently, whether an Arab state primarily should relate to expectations derived from the identity as an Arab state or as a sovereign state. ${ }^{31}$ While projecting an Arab self-image of which Palestine was an integral part, one group of players - including conservative pro-Western monarchies such as the Hashemite Kingdoms in Jordan and Iraq (until 1958) as well as the Kingdom of Saudi Arabia - subscribed to a weak Political Arabism similar to the ideas formulated in the Arab League charter about interstate cooperation between sovereign Arab states within an Arab framework of brotherhood, solidarity and coordination. This position was challenged by the 'radical' and nominally socialist Arab republics such as Egypt, Syria and after 1958 also Iraq. These states followed the Pan-Arab view that the interest of a common Arab nation should take precedence over the individual Arab states. The ultimate goal was - at least in principle - the emergence of a single Arab nation-state encompassing all Arabic-speaking territory, including the territory of Palestine, along lines similar to the merger between Syria and Egypt in the (short-lived) United Arab Republic. ${ }^{32}$

The scene of rivalry between these two Arab blocks was not delimited to the regional level. The Arab Cold War was marked by a complex interplay between the regional and domestic levels making the Arab world look like 'a set of interconnected organisms separated only by porous membranes, or, alternatively a large-scale domestic system divided into compartments of varying degrees of permeability. ${ }^{33}$ Domestic politics did also take place at the regional level, where Arab regimes lacking electoral legitimacy tried to gain domestic support by

${ }^{28}$ Hinnebusch, International Politics.

${ }^{29}$ Walid Kazziha, 'The Impact of Palestine on Arab Politics', in Ghassan Salamé and Giacomo Luciani (eds), The Politics of Arab Integration (London: Croom Helm, 1988), pp. 300-18.

30 Michael Barnett, Dialogues in Arab Politics: Negotiations in Regional Order (New York: Columbia University Press, 1998).

31 Barnett, Dialogues in Arab Politics.

32 The United Arab Republic (UAR) existed between 1958 and 1961. Cf. Barnett, Dialogues in Arab Politics, pp. $129 \mathrm{ff}$.

33 Noble, Arab System, p. 57. 
presenting themselves in the service of a higher Arab cause. At the same time, regional rivalries also involved the domestic level. The interconnectedness of the Arab states and the permeability of their borders thus provided aspiring regional Arab powers a unique opportunity for meddling in the domestic politics of other Arab states based on claims of acting on behalf of the Arab nation. ${ }^{34}$ As a consequence Arab politics during the era of the Arab Cold War was marked by interventions in each other's internal affairs on a scale unseen anywhere else, including other parts of the post-colonial world. A classic expression of this remarkable 'low salience of sovereignty' ${ }^{35}$ is Nasser's famous speeches at the Egyptian radio station Sawt al'Arab (Voice of the Arabs), which resonated throughout the Arab 'sound chamber' allowing Nasser to bypass local leaders and appeal directly to populations in other Arab countries. In contrast to the assumption in much of Realist IR theory, these radio speeches appeared to many other Arab leaders as a greater security threat than the Egyptian military. This points to yet another distinct feature of the Arab Cold War: The predominant means employed was less 'hard' military power than 'soft power' in terms of ideological appeal and the legitimacy derived from being perceived to observe the norms and play the roles grounded in Arab nationalism. ${ }^{36}$ Here the Palestine issue constituted a key role as it behind the nominal united Arab support to the Palestinians constituted the arena for this inter-Arab rivalry. ${ }^{37}$ While the Arab Cold War - with the exception of clashes between Egypt and Saudi Arabia in the Yemeni civil war in the 1960s - seldom evolved into 'hot' warfare like the Arab-Israeli conflict, the conflict was not without impact: the 1950s and 1960s not only saw a series of popular revolts and coup (attempts) by Pan-Arab officers. They also witnessed puzzling foreign policy adventures incompatible with a strict raison d'état but necessary to counter charges of being in conflict with the 'Arab cause'. In order to understand King Hussein's willingness to be dragged into the fatal 1967 war, in which Jordan lost East-Jerusalem and the West Bank, instead of trying to balance the threats from the Egyptian and Syrian Pan-Arab regimes by an open alliance with Israel, one must for instance consider that the likely alternative was popular revolts against the Hashemite monarchy supported by 'radical' Arab states. ${ }^{38}$ In a similar vein, Egypt's road to the defeat in the 1967 war has been interpreted as Nasser being trapped by his own rhetoric, which was part of an outbidding spiral among competing 'radical' Pan-Arab states that all aspired to being the true defender of 'the Arab cause'. ${ }^{39}$

34 On permeability cf. Bassel F. Salloukh and Rex Brynen (eds), Persistent Permeability? Regionalism, Localism and Globalization in the Middle East (Aldershot: Ashgate, 2004).

${ }^{35}$ Fred Halliday, 'The Middle East and Conceptions of "International Society", in Barry Buzan and Ana Gonzalez-Pelaez (eds), International Society and the Middle East - English School Theory at the Regional Level (New York: Palgrave, 2009), p. 15.

${ }^{36}$ Bahgat Korany, 'The Arab World and the New Balance of Power in the New Middle East', in Michael C. Hudson (ed.), Middle East Dilemma - the Politics and Economics of Arab Integration (London: I. B. Tauris, 1999), p. 57.

37 Kazziha, 'Impact of Palestine'.

${ }^{38}$ Barnett, Dialogues in Arab Politics, p. 158. Cf. also André Bank and Morten Valbjørn, 'Bringing the Arab Regional Level Back in... - Jordan in the New Arab Cold War', Middle East Critique, 19 (2010), p. 308f.

39 Raymond Hinnebusch, 'The Foreign Policy of Egypt', in Raymond Hinnebusch and Anoushiravan Ehteshami (eds), The Foreign Policies of Middle East States (London: Lynne Rienner, 2002), pp. 91-114. 


\subsection{The transformation of Arab nationalism: a societal Political Arabism in an Arab-Islamic public}

The 1967 war highlights some of the distinct features of Arab politics during this Arab Cold War, including the distinctly Arab frame of reference, the remarkable low salience of sovereignty, the complex interplay between domestic and regional politics and the 'hard' impact of 'soft power'. According to the conventional narrative, the Arab debacle at the same time also marked the beginning of the end of Arab nationalism. In the following decades a prominent literature on the rise and fall of Arab nationalism has thus emerged. ${ }^{40}$ While differing on whether the final coup de grace was marked by the 1967 war, the Egyptian/Israeli peace treaty at Camp David in 1978-9, the Second Gulf War 1990-91 or by the US invasion of Iraq in 2003, these views agree on the more general point that Arab politics has ceased being Arab in the sense that a common Arab identity would influence the nature of regional politics. Not only is it allegedly no longer important for Arab regimes to be perceived in line with some kind of 'raison de la Nation Arabe', even the very existence of an Arab world is cast into doubt. ${ }^{41}$

Despite the popularity of these readings, it is also possible to identify another less influential strand which upholds the Arab world as a meaningful analytical category. Stephen Humphreys for instance argues that despite various local differences, Arabs do still feel an acute sense of a common and peculiar identity. He likens the political situation to that of family members who may quarrel but still feel strongly connected and suggests that this deep-seated sense of Arab identity is almost certain to have political consequences. ${ }^{42}$ This calls attention to how the demise of Pan-Arabism might not necessarily be conflated with the termination of Arab nationalism as such. ${ }^{43}$ Halliday for instance argues that the demise of Arab nationalism has been overstated and that it might be more useful to perceive Arab and state centered nationalisms to be coexistent or to work at different planes. $^{44}$

If it is rather Pan-Arabism than Arab nationalism that is obsolete, what would a transformed or modified form of Political Arabism look like? In contrast to Hussein Sirriyeh's interest in the nature of a new Arab interstate order based on the coexistence between Westphalian sovereignty and a weak Political Arabism, ${ }^{45}$ we find Shibley Telhami's discussion of a 'New Arabism' and Marc Lynch's reflections about a 'New Arab public sphere' more helpful. ${ }^{46}$ They provide a less narrowly state-centric perspective and constitute in combination a useful starting

${ }^{40}$ Fouad Ajami, 'The End of Pan-Arabism', Foreign Affairs, 57 (1978), pp. 355-73; for an overview of this debate, cf. Adeed Dawisha, Arab Nationalism in the Twentieth Century: From Triumph to Despair (Princeton: Princeton University Press, 2003).

${ }^{41}$ Zisser, 'Trends'.

42 Stephen Humphreys, Between Memory and Desire: The Middle East in a Troubled Age (Berkeley: University of California Press, 2000), p. 82.

${ }^{43}$ On the transformations of Arab nationalism before and after the 1950-60s cf. Valbjørn, 'Arab Nationalism(s)', pp. 157ff.

44 Fred Halliday, Nation and Religion in the Middle East (London: Saqi Books, 2000), p. 50.

${ }^{45}$ Hussein Sirriyeh, 'A New Version of Pan-Arabism?', International Relations, 15 (2000), pp. 53-66.

${ }^{46}$ Shibley Telhami, 'Power, Legitimacy and Peace-Making in Arab Coalitions - The New Arabism', in Leonard Binder (ed.), Ethnic Conflict and International Politics in the Middle East (Gainesville: University of Florida Press, 1999), pp. 43-60; Marc Lynch, Voices of the New Arab Public - Iraq, Al-Jazeera, and Middle East Politics Today (New York: Columbia University Press, 2006). 
point for an outline of what may be labelled as a societal Political Arabism in an Arab-Islamic public. The emergence of such a new and transformed form of Arab nationalism is related to two intertwined dynamics. The first concerns the long-dominant authoritarianism in the Arab world, which leaves narrow limits for open political expression. ${ }^{47}$ Instead, discontented citizens turn their attention to the regional level, using it as an indirect and less dangerous way of criticising the regimes in power. In this context, they raise the classic Arab nationalist question about Palestine or the issue of Iraqis' suffering, which emerged on the Arab agenda with the 1990s UN sanctions. This intertwining of regional and domestic issues is not new, but it attains a new dimension by a second dynamic related to the 1990s information revolution. The emergence of new trans-Arab media thus challenges the media monopolies gained by the local regimes in the decades following the Nasserist 'radio wars', where the state institutions had experienced a relative 'hardening'. ${ }^{48}$ The epoch-making event was the launching in 1996 of al-Jazeera, which provides the perfect platform for intensive discussions revolving around regional issues. ${ }^{49}$ Contrary to previous Arab satellite channels al-Jazeera emphasises news and political debate. As a commercial channel it is concerned with reaching the largest possible audience in the Arabic-speaking world. It stresses matters with a common Arab interest, such as Iraq or Palestine, or presents local issues within a broader Arab framework. By tying distant events together in a common Arab narrative, the new trans-Arab media have, according to Lynch, paved the way for the emergence of a 'new Arab public sphere'. ${ }^{50}$ This public is united by the Arabic language and a news agenda revolving around 'Arab issues' through which speakers and listeners conceive of themselves as taking part in a single, common political project - pretty much what EU enthusiasts can only dream of. In Arab opinion polls large majorities thus rank the Palestine issue as one of the most important political issues to them personally. They further indicate that Arabs still evaluate non-Arab countries based on those countries' policies toward key regional Arab issues, that is Palestine and Iraq, rather than their specific behaviour toward their own country. ${ }^{51}$

If today's Arab world, partly owing to the new trans-Arab media, resembles an identity-bounded enclave, it is obvious to draw comparisons to the 1950-60s Arab 'sound chamber' in which ideas resonated with little regard for state frontiers. While trans-Arab media were also playing an important role at that time a comparison between Nasser's Sawt al-Arab and today's al-Jazeera highlights at the same time some of the distinct traits of the new form of Arab nationalism: while

${ }^{47}$ It remains to be seen to what extent and in what ways the 'Arab Spring' of 2011 will really change the traditionally prevalent authoritarianism in the region.

48 On the 'hardening' of state institutions in the Arab world cf. F. Gregory Gause, 'Sovereignty, Statecraft and Stability in the Middle East', Journal of International Affairs, 45 (1992), pp. 441-69. Besides the rise of the new trans-Arab media, this 'hardening' has also been challenged by privatisation policies in recent decades leading to the restructuring of state power across the region. Cf. Laura Guazzone and Daniela Pioppi (eds), The Arab State and Neo-Liberal Globalization. The Restructuring of State Power in the Middle East (Reading: Ithaca, 2009).

49 On new Arab media and Arab nationalism cf. Lawrence Pintak, "Border Guards of the "Imagined" Watan: Arab Journalists and the New Arab Consciousness', Middle East Journal, 63 (2009), pp. 191-212.

50 Lynch, New Arab Public.

${ }^{51}$ Peter A. Furia and Russell E. Lucas, 'Determinants of Arab Public Opinion on Foreign Relations', International Studies Quarterly, 50 (2006), pp. 585-605. 
Sawt al-Arab was an ideological tool wielded by a regional power, al-Jazeera is a commercial, quasi-independent station driven by market demand and based in tiny Qatar. Moreover, Nasser's 'one-way' radio speeches were based on a monological principle - not only in concrete terms but also in a more figurative sense as his Pan-Arabism assumed unity and binding consensus among Arabs, leaving little space for legitimate disagreements. Al-Jazeera, on the other hand, is more dialogical in nature. This dimension is found in the audience polls, popular political talk shows and in the possibility for viewers to call in asking questions or expressing their opinions. The prominence on al-Jazeera of the aforementioned famous Islamist figure al-Qaradawi hosting the popular programme 'Islamic Law and Life' illustrates a final important difference: the growing Islamic dimension in today's Arab identity in contrast with the secular pan-Arabism of the 1950s and 1960 s. $^{52}$

To sum up, what we may be witnessing is an Arab nationalism embedded in an Arab public with an Arab-Islamic identity as the common reference point and united around a common agenda defining certain 'Arab issues'. However, contrary to the past it is more an agreement on what to disagree about, because no definitive answer as to what 'the Arab position' on a given issue is provided. According to polls, an agreement about the paramount importance of the Palestine issue by no means equals a consensus about the preferred solution. ${ }^{53}$ Similarly, while Arabs state that watching Arab television makes them feel closer to Arabs elsewhere, they sense at the same time that differences between Arabs are growing. ${ }^{54}$ It is against this historical and conceptual background that we now revisit the 2006 Lebanon War and the debate of the possible lessons this conflict holds for the emerging regional constellation in the Middle East.

\section{The emergence of the New Arab Cold War: the 2006 Lebanon War revisited}

In view of its largely societal nature, the important role ascribed to popular media, and the lack of definitive and agreed-upon 'Arab answers', it is obvious to wonder whether one should consider this transformed version of Arab nationalism as an example of Political Arabism or whether it is rather an expression of Cultural Arabism without any political significance.

As explained above, the initial official, state-based Arab reactions to Hizballah's cross-border raid and the ensuing Israeli bombardment of Lebanon in the summer of 2006 seem to support both the latter Cultural Arabism position and the prevalent assumption about the post-Arab nature of the 'New Middle East'. A closer look at the pattern of the regional reactions reveals however a different picture, one supporting the view that regional politics still holds a distinct Arab dimension with implications within and beyond the interstate levels. By combining the reflections on a new form of Arab nationalism with the earlier discussion about the nature of Arab politics of the 1950-60s, these regional reactions can thus be

\footnotetext{
52 On the Islamisation of Arab nationalism cf. Oliver Roy, The Politics of Chaos in the Middle East (New York: Columbia University Press, 2008).

53 Shibley Telhami, 'America in Arab Eyes', Survival, 49 (2007), pp. 107-22.

${ }^{54}$ Lynch, New Arab Public, p. 4.
} 
perceived in terms of a 'New Arab Cold War' marked by structural similarities with but also specific differences from the old version. ${ }^{55}$

Besides the explicit equation made at demonstrations between 'Nasrallah 2006' and 'Nasser 1956', the 'New Arab Cold War' is, like the old one, 'cold' in the sense of a symbolic rivalry, where 'soft power' is more important than military 'hard power'. Both are likewise marked by a complex interplay between domestic and regional theatres and are about monopolising the meaning of the 'common Arab interest' and discrediting the adversary's Arab credentials. At variance with the usual emphasis on its Shi'i nature, Hizballah was very keen on and successful in presenting itself as an Arab movement concerned about Arab solidarity, the liberation of Palestine and resistance to occupation. ${ }^{56}$ Although Egypt, Jordan and Saudi Arabia's denunciations of the Shi'i-Arab Hizballah are often presented as proof of their post-Arab nature, a closer look at how and why these regimes launched their critique reveals another picture. Their charge against Hizballah's 'adventurism' was, for example, substantiated with reference to how the actions did 'not serve Arab interests'. ${ }^{57}$ A likely explanation as to why they were so explicit in their critique is the Arab regimes' general fear of popular Arab-Islamic social movements largely beyond their control. From this perspective, Hizballah's challenge to Israel under Arab-Islamic colours presented an indirect threat to these regimes. By acting rather than simply talking about the 'Arab cause', Hizballah exposed the hollowness of the Arab regimes' own promises. At the same time, the head-on clash with Israel's military superiority also held out the possibility that in the case of a swift Israeli victory - Hizballah would be cut down to size, literally and figuratively. Thus, the 'moderate Sunni Arab states' seem to have reacted to the Lebanon War 2006 in ways similar to the Old Arab Cold War. Sensitive to the interrelation of Arab regional issues and their (lack of) domestic legitimacy, they attempted to discredit a rival with accusations of harming 'the Arab interest'. A further indication for this was the three pro-Western Sunni Arab states' change of course as the civilian casualties of Israeli bombings rose in the full glare of the cameras of al-Jazeera. They began distancing themselves rhetorically from the US and Israel and instead tried to raise their Arab profiles by sending humanitarian aid. In the war's aftermath, they were very keen on recapturing the Palestine torch from Arab-Islamic societal actors, by playing a mediating role for a Palestinian national unity government and by reintroducing the Arab Peace Initiative.

An obvious objection to this framing is the close links between Hizballah and Iran. At first glance, this non-Arab dimension highlights the difference from the 1950-1960s. But Iran's attempts to gain influence in the Arab world still fit into the New Arab Cold War framework. Thus, non-Arab Iran did so by tapping into a classic Arab nationalist narrative, sometimes even at al-Jazeera, presenting

\footnotetext{
55 The New Arab Cold War conception also acknowledges the importance of shifts in the global political structure for regional politics in the Middle East. In this article, however, we concentrate primarily and almost exclusively on the regional level of Middle Eastern politics. For a more substantial analysis of the global-regional interplay cf. Morten Valbjørn, 'The 'New Middle East' and the Encounter with the Global Condition', in Stephan Stetter (ed.), Globalisation and the Middle East, forthcoming. For a thorough analysis of the regional-domestic interplay in the New Arab Cold War context cf. Bank/Valbjørn, Jordan, pp. $313 \mathrm{ff}$.

${ }^{56}$ Fuller, 'Hizballah-Iran Connection'.

57 Valbjørn/Bank, 'Signs'.
} 
itself - apparently rather successfully - as 'more Arab than the Arabs' ${ }^{58}$ Contrary to the frequent anti-Iranian remarks by 'moderate Sunni Arab' leaders, the controversial Iranian president, Mahmud Ahmadinejad, came in second in Egyptian post-war polls about the identity of 'the most important leader in the region.' Only Nasrallah surpassed him, and another Arab-Islamist leader, Khalid Mish'al of Hamas, followed close on his heels. ${ }^{59}$ Just as noteworthy, this Arab profile did not gain the Iranian president much credit among his own population, which is part of the Middle East, but not the Arab world.

It is, however, not only Iran's new role as a player in the Arab game of politics which makes it necessary to speak of a 'New Arab Cold War'. While depicting 'Nasser 1956' alongside 'Nasrallah 2006' was intended to establish similarities between the two figures, the comparison aptly illustrates the differences between then and now. Whereas in the 1950s the 'radical' torchbearer was the secular, socialist-leaning president of a leading regional power, in 2006 the head of an Islamist social movement was hailed as 'the only true Arab leader today'. ${ }^{60}$ In other words, a societal Political Arabism rising from an Arab-Islamic public rather than a state-led Pan-Arabism constitutes a dominant frame of reference in Middle East politics during the first decade of the 21st century. Moreover, not only are relations between key players transformed - Egypt and Saudi Arabia have turned from adversaries into allies, for instance - but the nature of actors has also changed. Societal actors, not upstart republics, now represent the 'radical' challenge. The rivalry is no longer primarily an interstate competition, but a Cold War between Arab states, or regimes, and societal actors lead by Islamists with considerable popular support and subscribing to a popular driven Islamic Political Arabism. The impact of this rivalry is as a consequence also different. While the old Arab Cold War was associated with coup d'état (attempts) and grand pan-Arab unity schemes, the new societal Islamic Political Arabism is less about challenging the existing state system. The impact should rather be located in a growing delink between states and societies with the populations dissociating themselves from largely delegitimised authoritarian Arab regimes.

In sum, by combining insights from recent studies on the transformation of Arab nationalism and the literature on the Old Arab Cold War, it is possible to account for a number of distinctly Arab patterns in the regional reactions to the Lebanon War 2006, ones ignored by the prevalent narratives about this conflict. Our findings moreover call into question the prevalent claims that we are witnessing a completely new regional constellation that marks an absolute break with previous periods. As shown, it is to the contrary possible to identify a number of structural similarities in the regional reactions between the 2006 Lebanon War and the Old Arab Cold War of the 1950-60s. This does not imply that the conflict was nothing but a replay of an old game of Arab politics. ${ }^{61}$ In view of the

\footnotetext{
${ }^{58}$ On Iran playing 'the Arab card' cf. Roy, The Politics of Chaos, p. 117.

59 This regime/people divide as regards the perception of Iran can also be traced in a more recent Arab opinion poll. Contrary to the hype about Arab support for a US attack on Iran based on official Arab statements about an 'Iranian threat', 57 per cent of the Arab public did in 2010 describe Iran's possession of nuclear weapons as a 'more positive' development for the Middle East region. Cf. Shibley Telhami, 2010 Arab Public Opinion Poll (5 August 2010).

${ }^{60}$ Dan Murphy, 'In war's dust, a new Arab 'lion' emerges', Christian Science Monitor (29 August 2006).

${ }^{61}$ Barry Rubin, 'Arab Politics: Back to Futility', Middle East Quarterly, 14 (2007), pp. 53-62.
} 


\begin{tabular}{|c|c|c|}
\hline & The Old Arab Cold War & The New Arab Cold War \\
\hline Context & \multicolumn{2}{|c|}{ 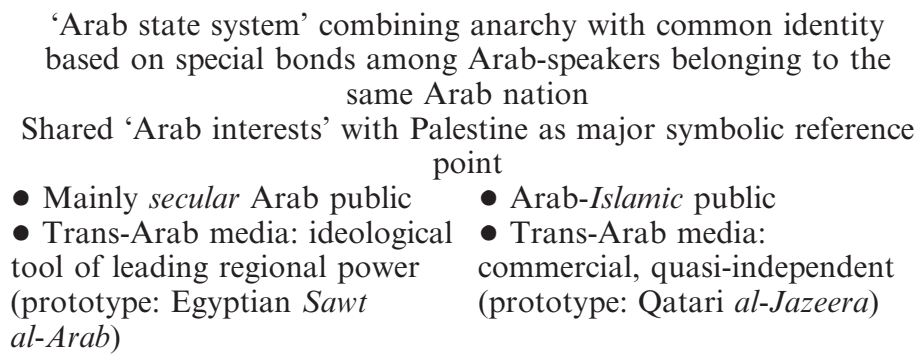 } \\
\hline Rivalry & $\begin{array}{l}\text { About monopolising the m } \\
\text { discrediting rivals as a } \\
\text { - Interstate }\end{array}$ & $\begin{array}{l}\text { eaning of Arab interests and } \\
\text { cting at odds with them } \\
\text { - states/regimes vs. Islamist } \\
\text { societal actors with popular } \\
\text { appeal }\end{array}$ \\
\hline Players & Arab actors : & $\begin{array}{l}\text { - Arab states and Arab-Islamist } \\
\text { societal actors as well as } \\
\text { non-Arab Iran, Israel and } \\
\text { Turkey }\end{array}$ \\
\hline Cleavage & $\begin{array}{l}\text { Pro-Western 'moderate' } \\
\text { - 'Radical': secular, } \\
\text { socialist-leaning regimes } \\
\text { (prototype: Nasser) } \\
\text { - Key opponents: Egypt vs. } \\
\text { Saudi-Arabia }\end{array}$ & $\begin{array}{l}\text { vs. anti-Western 'radicals' } \\
\text { - 'Radical': Arab-Islamist } \\
\text { movements (prototype: } \\
\text { Nasrallah) } \\
\text { - Key opponents: Egypt \& } \\
\text { Saudi Arabia vs. Hizballah \& } \\
\text { Hamas }\end{array}$ \\
\hline Means & $\begin{array}{l}\text { 'Soft power': popular legitimacy } \\
\text { observe 'Arab interests' more } \\
\text { - Arab League } \\
\text { - Radio (Sawt al-Arab) }\end{array}$ & $\begin{array}{l}\text { derived from being perceived to } \\
\text { threatening than military 'hard' } \\
\text { wer } \\
\text { - 'Duelling Arab Summits' } \\
\text { Trans-Arab satellite channels } \\
(\text { al-Jazeera, al-Arabiya) }\end{array}$ \\
\hline Theatre of rivalry & $\begin{array}{l}\text { Domestic regime/people divid } \\
\text { regional politics do also ta }\end{array}$ & $\begin{array}{l}\text { e related to regional scene and } \\
\text { ke plays at domestic scene }\end{array}$ \\
\hline Impact & $\begin{array}{l}\text { Foreign policy at odds with nar } \\
\text { protests at } \\
\text { - Popular revolts and coup } \\
\text { (attempts) }\end{array}$ & $\begin{array}{l}\text { row raison d'état as a reaction to } \\
\text { oopular level } \\
\text { - Rise of a parallel non-statist } \\
\text { Arab order next to official Arab } \\
\text { state system } \\
\text { - Further delegitimised Arab } \\
\text { authoritarianism }\end{array}$ \\
\hline
\end{tabular}

Table 1. Comparing the Old and New Arab Cold War

described differences between the nature of inter-Arab relations then and now it might be more accurate to portray Lebanon 2006 as a qualified return in terms of a New Arab Cold War, as outlined in Table 1. 


\section{The New Arab Cold War continued: the Gaza War 2008-9}

While it was possible to detect a distinct Arab dimension in the regional reactions to the 2006 Lebanon War, this does not necessarily mean that our understanding of a New Arab Cold War applies more generally to Middle East regional politics in the making. In order to examine to what extent the identified dynamics were only restricted to the regional context of Lebanon 2006, this section focuses on the Gaza War, where growing tensions between Israel and Hamas at the turn of 2008-09 escalated into open and bloody warfare. ${ }^{62}$ Akin to Lebanon 2006, the very 'hot' clashes in Gaza 2008-09 were accompanied by a regional 'cold' conflict taking place at state as well as popular levels. In this sense, the Gaza War has also been broadly perceived as an indicator of the changing nature of regional politics in the Middle East and some of the same narratives presented in the context of the Lebanon War have reappeared. ${ }^{63}$

Recalling the above table and turning to the regional reactions to the Gaza War, it again makes sense to speak of a distinctly Arab context, with Palestine as the major mobilising symbol. On the one hand, the scale of protests during the Gaza War all over the Arab world supports this view. Humanitarian relief initiatives and huge demonstrations took place in neighbouring countries with Palestinian populations such as Jordan, Syria, Lebanon and Egypt. This was also the case in more distant Arab countries in the Maghrib, the Gulf or Sudan. The media coverage of these demonstrations underscored the existence of a trans-state Arab public and even likened them to the re-emergence at the popular level of long-abandoned ideas and rhetoric from the 1950-60s, that is, the era of the Old Arab Cold War. ${ }^{64}$ On the other hand, it is obvious that the Gaza War also holds a strong(er) Islamic dimension. Hamas' rhetoric more explicitly stressed Islamic references, especially when compared to Hizballah's openly Arab nationalist discourse in 2006. Together with the prevalence of huge demonstrations also in non-Arab Muslim countries such as Turkey, Iran, Indonesia and Afghanistan, this raises the important question of whether the relevant regional context is Muslim rather than Arab. While it makes sense to perceive the Gaza War also in a wider Islamic context, a closer look reveals that a specific Arab context still matters: Outside the Arab world, demonstrations were first and foremost directed at Israel and the US, whereas the Islamist, leftist and liberal protesters in Arab countries also targeted Arab regimes, in particular Egypt which was accused of having approved of the Israeli attack and by this having acted against the 'proper' Arab behaviour. ${ }^{65}$ In view of Turkish prime-minster Recep Tayyip Erdogan's very vocal critique of Israel during the Gaza War, it is moreover striking how Hamas in an opinion poll after the conflict only received 5 per cent positive approvals among the Turkish populations, whereas the support to the Arab Islamist movement in

62 The war left more than 1,300 Palestinians dead and large parts of the socioeconomic infrastructure in the Gaza Strip destroyed. Cf. Human Rights Council, Human Rights in Palestine and other Occupied Territories. Report of the UN Fact Finding Mission on the Gaza Conflict (15 September 2009).

${ }^{63}$ For the moderate-radical narrative of the Gaza War cf. Asher Susser, 'The War in Gaza - A View from Israel' (RUSI.org 2009). The sectarian narrative has been partly superseded by the view that Hamas fights a proxy war for Persian-Shi'i Iran, cf. Yossi Klein Halevi and Michael B. Oren, 'In Gaza, the Real Enemy Is Iran', Los Angeles Times (4 January 2009).

${ }^{64}$ Ramzy Baroud, 'Gaza: A New Middle East Indeed', Middle East Times (12 January 2009).

${ }^{65}$ Nicholas Blanford, 'Deepening Israeli Assault on Hamas Divides Arab World', Christian Science Monitor (9 January 2009). 
Egypt and Jordan ran as high as 56 and 52 per cent. ${ }^{66}$ As for Iran, it is in a similar way noteworthy how one of the slogans of the Green Movement during the demonstrations after the controversial Iranian presidential elections in June 2009 was 'No Gaza. No Lebanon. My life to be sacrificed for Iran'.

The previous point about divisions among Arabs brings us to another set of questions to be examined concerning the nature of the rivalry, the major cleavages and relevant political players. Like in the 2006 Lebanon War, rhetoric about, and also a sense of, special bonds between Arabs did not translate during the Gaza War into much Arab unity or cooperation. Instead, a distinct but well-known rivalry took place within an Arab frame of reference with the players trying to monopolise their own meaning of Arab interests in order to discredit rivals as acting at odds with them. Besides calls for 'Arab fraternity and unity of every Arab', Saudi Arabia tried during the Gaza War to (im)prove her Arab credentials by donating one billion US dollars for rebuilding Gaza and at the end of the war warned Israel that the Saudi-promoted Arab Peace Initiative might be withdrawn. In a similar way, Egypt presented her efforts to mediate a ceasefire as being in the common Arab interest just as Qatar explained that its hosting of the Doha Arab Summit was meant to unify the Arab position. At the same time, accusations were rapidly exchanged for serving Israeli and/or Iranian rather than Arab interests. Egypt and Saudi Arabia presented Hamas as a mere pawn of non-Arab Iran. In turn, Hizballah's Nasrallah charged Egypt with conspiring with Israel against the Arab cause and on al-Jazeera Saudi Arabia and Egypt were charged for being passive and silent, while Arabs were 'massacred' in Gaza. ${ }^{67}$

The basic cleavage thus resembled the Lebanon War's polarisation of an Arab world divided between a pro-Western, 'moderate' camp represented by Egypt and Saudi Arabia and an anti-Western, 'radical' camp in which Hamas and Hizballah played a pivotal role. At the same time, the Doha summit of mid-January 2009 also highlighted some important differences. On the one hand, the presence of and key role attributed to Hamas' Khaled Mish'al illustrates the growing importance of societal Arab-Islamist actors - a key feature of the New Arab Cold War. On the other hand, the summit hosted by Qatar with 13 of the 22 Arab states participating, but without Egypt and Saudi Arabia, indicated how the cleavage is also present at the interstate level and thus constitutes more than a regime-peoples' divide. As in the Old Arab Cold War, there was a clear polarisation of the Arab states, with Qatar having assumed a leading (state) position among the 'radicals'. Contrary to its high-profile position among the 'moderates' during the 2006 Lebanon War, Jordan portrayed itself in the Gaza conflict as outside of any camps. ${ }^{68}$ Another interesting aspect of the Doha Arab summit was the surprising presence of Ahmadinejad. Again, this underscores the growing importance of non-Arab players and some observers have seen this as a proof of how Arab politics has ceased to be

${ }^{66}$ Pew Global Attitudes Project, Little Enthusiasm for Many Muslim Leaders - Mixed Views of Hamas and Hizballah in Largely Muslim Nations (Washington DC: PEW \{www.pewglobal.org\}, 2010).

${ }^{67}$ Under President Mubarak, the Egyptian regime's approach with regard to Gaza, for instance by keeping the Rafah border crossing closed, was less driven by a sense of 'positive cooperation' with Israel. Rather, it can be explained by the fear of a political success for the Palestinian Hamas, which could then serve as an inspiring example for the Egyptian Muslim Brotherhood and, generally, for the strength of status quo challenging Arab-Islamic organisations - a key characteristic of the New Arab Cold War.

${ }^{68}$ Bank/Valbjørn, Jordan, p. 316. 
Arab. ${ }^{69}$ While Iran certainly plays an important role in regional politics today, this does not necessarily counter our argument about the existence of a distinct game of Arab politics. As outlined above, Iran was trying to gain influence in the Arab world by behaving 'more Arab than the Arabs', especially when it came to presenting itself as the 'real defender of the Palestinian cause', thereby insinuating that the 'real enemies' of the Arab people are their own regimes. This points to the multiple theatres of rivalry and the means in the New Arab Cold War. As for the former, it already appears from the discussion so far that the rivalry in the Gaza War also took the form of a complex interplay between domestic and regional scenes. During the Gaza War, the Arab populations identified even more strongly than in the context of Lebanon 2006 with the 'radical', here pro-Hamas camp. In view of the already existing regional polarisation, this domestic divide made the regimes in Egypt, Jordan and Saudi Arabia extremely sensitive to the developments in Gaza and vulnerable to critique by their own populations for failing to support the Palestinians. In this sense, Hamas was perceived as a danger by Arab regimes not because of its alleged links to Iran but because of its impact on their own populations. ${ }^{70}$ When it comes to the means employed in the collusion between the Arab camps, it is also possible to recognise in the Gaza War a classic feature of both the Old and the New Arab Cold War: It was mainly a symbolic rivalry where 'soft power' was more important than military 'hard power'. One of the key battles of this Cold War was fought among trans-Arab media as an interpretative struggle on whether the Israeli attacks should be framed as being directed against Gaza or Hamas. ${ }^{71}$

The impact of the Gaza War with regard to regional politics in today's Middle East was multifaceted. First, it is possible to identify the same kind of arguments employed by the 'moderate' Arab regimes in the course of the Gaza War as during the conflict in Lebanon 2006. Against the background of popular sentiments, an initially rather harsh anti-Hamas and anti-Hizballah language was replaced in favour of more anti-Israeli statements. This rhetorical shift came without significant changes in policies. Despite popular calls to annul their peace treaties, both Egypt and Jordan refrained from revising their formal ties to Israel. It was only Qatar as one of the new players in regional politics together with Mauritania, whose new and fragile military regime was in need of legitimacy, which did freeze their ties to Israel. Secondly, the conflict contributed to a further polarisation in the Arab World as well as to a strengthening of the 'radical' camp, at least until the 'Arab Spring' starting in early 2011. Thirdly, this polarisation was also reflected in the widening regime-peoples' divide, making the Arab regimes appear even more illegitimate to their own populations, whereas the Islamist movements have gained further popularity in the course of the conflict escalation.

\section{Conclusion: Lessons for the study of Middle East politics and IR theory}

This article has provided an alternative conceptual lens to as well as a thick interpretation of the central dynamics of Middle East regional politics today. At

\footnotetext{
${ }^{69}$ Halevi/Oren, Real Enemy Iran.

70 Rami Khouri, 'Gaza's Impact on the Arab World', Agence Global (7 January 2009).

71 Marc Lynch, "Gaza" or "Hamas", Abu Aardvark Blog (2 January 2009).
} 
the immediate level, we have aimed at contributing to one of the much-discussed controversies in recent years' Middle East politics: The question about the nature of a 'new Middle East'. As shown, it is possible to identify the prominent moderate-radical, sectarian and Realist-Westphalian narratives, which despite their internal disagreements share an emphasis on the distinct post-Arab nature of regional politics in Middle East. Rather than supplanting these narratives as such, our aim has been to supplement them by drawing attention to the Arab dimension of the current regional constellation, which has been wrongfully neglected in the various post-Arab claims. Through our understanding of a 'New Arab Cold War', which rediscovers insights from Arab politics of the 1950-60s and combines them with recent discussions on the transformation of Arab nationalism, we have provided nuances to the frequent claims about the 'newness' of the 'new Middle East'.

In addition to this more Middle East-specific contribution, our discussion of the New Arab Cold War and the highlighting of the Arab dimension in regional politics do at a more general(ist) level also connect to and carry important lessons for prominent debates in the study of world regions and IR theory. Most obviously, our discussion connects to the question of the regional level in the study of International Relations, which as already mentioned has experienced a growing attention in the general IR debate. ${ }^{72}$ The matter of dispute in this debate has not only concerned the question about the proper levels-of-analysis, that is, the relative importance of a regional level compared to, typically, the global. ${ }^{73}$ It has also been closely related to the question about whether it is possible to tell one coherent and homogeneous story about international relations around the globe or if it is necessary to recognise that there are distinct stories at several levels with none holding the master key to a full interpretation. ${ }^{74}$ Thus, an agreement about the importance of the regional level does not necessarily preclude disagreements on whether dynamics in different regions are assumed to basically follow the same universal logics or if it is necessary to account for distinct and more region-specific dynamics. ${ }^{75}$ This general issue constitutes in many ways an underlying theme in our examination of the nature of the 'New Middle East'. As shown in the preceding sections, if one adopts a rather narrow state-centric perspective one will primarily notice how the relations between the Arab states today, in contrast to the very low salience of sovereignty during the 1950-60s, appear to be resting on mutual recognition and an increasing respect of the principle of non-intervention; how grand pan-Arab unity schemes implying radical changes of the existing state-system are absent from the Arab agenda; and finally how non-Arab states such as Turkey and Iran are playing an increasingly important role in regional

${ }^{72}$ See references in fn. 2.

73 This controversy is not only played out between the various IR traditions but also within these. Within Realism, it is for instance possible to find both global-centric perspectives, for example, Birthe Hansen, Unipolarity and the Middle East (New York: St. Martin's Press, 2001), and regional-centric perspectives, Efraim Karsh, 'Cold War, post-Cold-War: does it make a difference for the Middle East?', Review of International Studies, 23 (1997), pp. 271-91.

74 Buzan/Wæver, Regions and Powers, p. 26.

75 This has been reflected in a debate on whether the Middle East is to be perceived as a region like 'any other' or like 'no other'. Cf. Morten Valbjørn, 'Culture Blind and Culture Blinded: Images of Middle Eastern Conflicts in International Relations', in Dietrich Jung (ed.), The Middle East and Palestine: Global Politics and Regional Conflicts (New York: Palgrave, 2004), pp. 39-78. 
politics. Against this background, the 'New Middle East' emerges at first sight as a 'region like any other' and regional politics appears both post-Arab and close to the classic Westphalian model. As we have shown, this perspective does however leave (too) much out of the picture.

By adopting a broader and more inclusive perspective, the importance of non-state actors in regional politics becomes obvious. ${ }^{76}$ Thus, both in the more 'hot' and 'cold' collisions of the first two major regional conflicts in the 'New Middle East' non-state actors, that is, Hizballah and Hamas, were playing a leading role. Moreover, it is also obvious that a growing respect for the principle of non-intervention among the Arab states does not mean that their borders are not any longer porous. At a society-society level the rise of the new trans-Arab media has on the contrary (re)created an 'Arab sound chamber' as recently noted by Noble, who against this background finds it premature to talk about the end of permeability and the full consolidation of the Arab regional system along the lines of the Westphalian model. ${ }^{77}$ This is reflected in a (still) complex interplay between domestic and Arab politics, in which Arab players are conscious about presenting themselves as being in line with the 'Arab cause'. This Arab public is also playing an important role in putting dynamics of the Arab world apart from other parts of the region, as reflected in the differences in the popular reactions in Arab and non-Arab societies to the two examined regional conflicts or to Ahmadinejad playing the 'Palestine card'. Finally, it is also clear that Arab states' mutual recognition has not translated into much popular recognition of these regimes resulting in a growing delink between states and societies.

From this broader perspective, it will therefore be necessary to supplement a coherent and neat Westphalian story with the messiness of distinct stories both at a broader regional and a more specific Arab levels leaving us with a picture of the 'New Middle East', which to a lesser degree appears as a 'region like any other'. This observation leads us to the first general lesson of this study. In debates on whether a specific region should be perceived as a region like any/no other, it is important to adopt a broader perspective. Our study does in this way support the direction taken for instance by the so-called New English School. Contrary to its classic version, the interest is here expanded not only to include regional international societies, but both the interstate and world society domains within these. ${ }^{78}$ A second general lesson concerns one of the hallmarks of the Westphalian model: the sovereignty institution. Thus, we agree with Gregory Gause that sovereignty should not be viewed as a given or a constant but rather as a disputed and evolving concept. ${ }^{79}$ Moreover, it appears useful to disaggregate the concept of sovereignty in various dimensions, for instance along lines suggested by Stephen

${ }^{76}$ For an example of how a growing attention to the regional level does not necessarily imply a concern for non-state actors and of how this may result in a neglect of distinct regional features, cf. Buzan/Wæver, Regions and Powers.

${ }^{77}$ Paul Noble, 'From Arab System to Middle Eastern System? - Regional Pressures and Constraints', in Bahgat Korany and Ali E. Hillal Dessouki (eds), The Foreign Policies of Arab States: The Challenge of Globalization (Cairo: American University Press 2008, 3rd ed.), pp. 67-167.

78 Barry Buzan, 'The English School: an underexploited resource in IR', Review of International Studies, 27 (2001), pp. 471-88; Barry Buzan, From International to World Society - English School Theory and the Social Structure of Globalization (Cambridge: Cambridge University Press, 2004); Barry Buzan and Ana Gonzalez-Pelaez (eds), International Society and the Middle East - English School Theory at the Regional Level (New York: Palgrave, 2009).

79 Gause, 'Sovereignty'. 
Krasner, ${ }^{80}$ in order to be better able at grasping whether a growing salience of one dimension of sovereignty, say 'Legal Sovereignty', is translated into for instance 'Interdependence Sovereignty' or 'Domestic Sovereignty'. A third general lesson is related to the debate on the deterritorialisation of International Relations, which often has been framed in a zero-sum game between the territorialised Westphalian state-system vs. some deterritorialised non-statist alternative. As an alternative to this either/or perspective it has more recently been suggested that territoriality and supra-territoriality instead should be perceived as coexisting in the sense of a simultaneous existence of state and non-statist orders operating alongside and through each other. ${ }^{81}$ Based on insights from our study this alternative conceptualisation seems to be both useful and convincing. Besides the fact that an Arab identity still appears to matter also among Arab states asserting themselves more and more, it thus appears that what we have described as a new societal Political Arabism along with the rise of new trans-Arab media should not be perceived as a challenge to the already existing, quasi-Westphalian state system as such. As we have explained, it is rather about the emergence of a parallel non-statist Arab order existing side by side and being in a tense and complex relationship with the official Arab state system. In addition to these points, as a fourth and final general lesson this article can also serve as a reminder of the potential merits of bringing the Middle East into the general IR debate through a dialogue between IR generalists and regional specialists. ${ }^{82}$

${ }^{80}$ Stephen Krasner, Sovereignty: Organized Hypocrisy (Princeton: Princeton University Press, 1999).

81 Barry Buzan, 'International Political Economy and Globalization', in Alex Bellamy (ed.), International Society and Its Critics (Oxford: Oxford University Press, 2005), pp. 131-5.

82 Cf. Andrea Teti, 'Bridging the Gap: IR, Middle East Studies and the Disciplinary Politics of the Area Studies Controversy', European Journal of International Relations, 13 (2007), pp. 117-45; Morten Valbjørn, 'Toward a 'Mesopotamian Turn': Disciplinarity and the Study of the International Relations of the Middle East', Journal of Mediterranean Studies, 14 (2004), pp. 47-75. 